Jurnal IImu Pengetahuan dan Pengembangan Masyarakat Islam ISSN: 2085-8833, E-ISSN: 2797-6963| Vol. 15, No. 2, Oktober 2021, pp. 76-92 http: http://ejournal.uin-suska.ac.id/index.php/Menara/index

\title{
Sosialisasi Bahaya Media Sosial Sebagai Modus Perdagangan Orang pada Remaja di Jatinangor
}

\author{
Benazir Bona Pratamawaty1, Evie Ariadne Shinta Dewi², Putri Limilia ${ }^{3}$ \\ ${ }^{123}$ Departemen Komunikasi dan Informasi, Universitas Padjadjaran \\ E-mail: benazir.bona@unpad.ac.id
}

\begin{abstract}
Abstrak
Periode Januari-April 2021 tercatat sebanyak 234 anak telah menjadi korban perdagangan orang, yang 60\% diantaranya merupakan korban yang direkrut melalui media sosial. Anak-anak dan remaja dimobilisasi dengan iming-iming pekerjaan enak bergaji besar yang kemudian dipaksa dan dieksploitasi secara seksual. Tingkat penetrasi internet yang tinggi dan kondisi pandemi membuat anak-anak dan remaja menggunakan dan mengakses internet dengan intensitas tinggi. Kondisi ini menempatkan mereka dalam posisi rentan dalam praktik perdagangan orang. Oleh karenanya, sosialisasi dan edukasi terhadap anak-anak remaja tentang bahaya media sosial sebagai modus perdagangan orang menjadi urgen untuk dilakukan. Fokus kegiatan pengabdian ini adalah untuk meningkatkan pengetahuan dan kesadaran remaja di Jatinangor tentang bahaya media sosial sebagai modus perdagangan orang. Teknik pengumpulan data meliputi survei daring sebelum (pre-test) dan sesudah (posttest) pelaksanaan sosialisasi. Dalam kondisi pandemi seperti ini, maka sosialisasi hanya bisa dilakukan secara daring dalam format Webinar. Webinar dilaksanakan dalam rangkaian tiga sesi, terdiri dari sesi polling berfungsi sebagai pre-test, sesi pembicara dan tanya-jawab, serta sesi post-test. Tujuan pelaksanaan webinar adalah untuk menyosialisasikan, mengedukasi, dan menimbulkan kesadaran sosial tentang ancaman perdagangan orang. Survei daring yang dilakukan kemudian dianalisis menggunakan metode deskriptif kuantitatif. Hasil post-test menunjukkan bahwa setelah mengikuti sosialisasi peserta memiliki pengetahuan dan pemahaman tentang modus-modus perekrutan perdagangan orang dan penggunaan media sosial sebagai salah satu modusnya.
\end{abstract}

Kata Kunci: Perdagangan orang; media sosial; sosialisasi; edukasi; penyadaran sosial

\begin{abstract}
In the period of January to April 2021, 234 children were found to be the victims of the children trafficking and 60\% of them were recruited through the social media. Children and young adults were told that they will be hired as employee and earn sophisticated salary while in fact they were tricked into sexual exploitation. Pandemic and high internet penetration results in increasing internet use for children and young adults. Hence, both children and young adults are prone to the human trafficking practices. Therefore, it is
\end{abstract}


urgent to conduct socialization and education towards children and young adults regarding the high risks of social media use as the recruitment tools for human trafficking perpetrators. This community service aimed to increasing knowledge and rising awareness of the young adults in Jatinangor with regard to the threat of social media as the human trafficking modus of practices. The data collection comprised of online survey before and after the socialization. Because of the pandemic, the socialization took place online or known as Webinar. The webinar was divided into three session which consisted of polling session (pre-test), talks and discussion session, then post-test session. The objectives of this webinar were to socialize, educate, and develop social awareness with regard to the human trafficking threats. The online survey results were analyzed using quantitative descriptive technique. The results indicate that after the webinar the participant succeed in gaining knowledge and understanding of the human trafficking recruitment modus and how the social media used as one of the modus.

Keywords: Human trafficking; social media; socialization; educate; social awareness

\section{Pendahuluan}

Perdagangan orang merupakan sebuah isu yang sangat kompleks dan multidimensional. Istilah perdagangan orang sendiri mungkin sudah dikenal masyarakat namun sayangnya isu ini belum menjadi salah satu persoalan sosial yang menjadi perhatian banyak orang. Menurut Undang-Undang Nomor 21 tahun 2007 tentang Pemberantasan Tindak Pidana Perdagangan Orang, perdagangan orang didefinisikan sebagai tindakan perekrutan, pengangkutan, penampungan, pengiriman, pemindahan, atau penerimaan seseorang dengan ancaman kekerasan, penggunaan kekerasan, penculikan, penyekapan, pemalsuan, penipuan, penyalahgunaan kekuasaan atau posisi rentan, penjeratan utang atau memberi bayaran atau manfaat, sehingga memperoleh persetujuan dari orang yang memegang kendali atas orang lain tersebut, baik yang dilakukan di dalam negara maupun antar negara, untuk tujuan eksploitasi atau mengakibatkan orang tereskploitasi.

Angka kasus perdagangan orang di Indonesia terus meningkat dari tahun ke tahun. Data yang dimiliki oleh International Organization for Migration (IOM) Indonesia menunjukkan besaran jumlah korban perdagangan orang di Indonesia pada periode tahun 2005-2017 mencapai 8.876 orang dengan korban terbanyak adalah perempuan. Sementara itu, pada triwulan pertama tahun 2018 saja sudah tercatat 32 kasus perdagangan orang yang teridentifikasi dengan korban anak-anak (Nabal, Wea, \& Gulo, 2018). Pada tahun 2017, pemerintah Indonesia memetakan dan menetapkan lima provinsi zona merah perdagangan orang, yakni provinsi dengan tingkat perdagangan orang yang tinggi karenanya menjadi zona merah. Lima provinsi zona merah tersebut terdiri dari Jawa Barat, Jawa Timur, Jawa Tengah, Nusa Tenggara Timur (NTT), dan Nusa Tenggara Barat (NTB) (Antara, 2017). 
Indonesia merupakan salah satu negara dengan tingkat kerawanan perdagangan orang yang tinggi karena memenuhi tiga unsur utama dalam aktivitas perdagangan orang, yakni perekrutan, penjualan, dan eksploitasi. Indonesia tidak hanya sebagai negara asal, tapi juga sebagai negara transit dan negara tujuan. Letak geografis Indonesia yang strategis didukung dengan rendahnya pengawasan jalur perbatasan menjadikannya sebagai negara transit dengan arus keluar-masuk manusia yang cukup tinggi. Selain itu, Indonesia juga sebagai negara tujuan bagi perempuan dari RRT, Belanda, Spanyol, Rusia, Thailand, Polandia, dan lain-lain karena masih lemahnya hukum terkait perdagangan orang (Daniah \& Apriani, 2017; Minin, 2011).

Sekumpulan besar studi telah dilakukan untuk menyelidiki faktor-faktor penyebab perdagangan orang di Indonesia. Adapun temuan dari sekumpulan studi tersebut menyatakan bahwa penyebab banyaknya kasus perdagangan orang di Indonesia diantaranya adalah kemiskinan, rendahnya tingkat pendidikan masyarakat, budaya patriarki yang memarjinalkan perempuan dalam tataran sosial-budaya masyarakat Indonesia, lemahnya penegakan hukum, ketidakmampuan pemerintah dalam menyediakan lapangan kerja, rentannya perbatasan antarnegara terhadap penyelundupan manusia, kurangnya perhatian aparat desa setempat terhadap anak yang putus sekolah, perilaku bebas remaja, sifat materialistik dan konsumtif masyarakat, serta korupsi pejabat pemerintah dan kolaborasi (Dalimoenthe, 2018; Daniah \& Apriani, 2017; Minin, 2011; Niko, 2016; Satriani \& Muis, 2013; Sylvia, 2014; Wulandari, 2016).

Deretan Panjang faktor penyebab terjadinya perdagangan orang tersebut menunjukkan kompleksitas permasalahan isu ini. Kondisi geografis Indonesia yang sangat beragam menghasilkan kondisi sosio-psikologis masyarakat yang juga sangat beragam. Hal ini menuntut penanganan isu perdagangan orang yang berbeda-beda berdasarkan kondisi daerahnya masing-masing. Sebuah studi menghasilkan beberapa strategi dalam rangka penanganan perdagangan orang di Indonesia, yang terbagi dalam dua kegiatan utama, yakni pencegahan dan penanggulangan. Tahapan pencegahan memerlukan sosialisasi komprehensif dan kontinu mengenai modus operandi dari sindikat perdagangan orang yang melibatkan seluruh komponen masyarakat, khususnya tokoh agama, tokoh adat, organisasi pemuda dan LSM. Sementara itu, penanggulangan merupakan tahapan yang mengutamakan penyelamatan dan rehabilitasi korban perdagangan orang (Minin, 2011).

Selain itu, studi lainnya juga menghasilkan rekomendasi yang serupa, bahwa upaya pencegahan harus segera dilakukan oleh pemerintah. Pemerintah harus mampu mengomunikasikan isu perdagangan manusia kepada masyarakat melalui kegiatan sosialisasi, menyebarkan informasi, serta menyelenggarakan pelatihan dan pendidikan bagi masyarakat di wilayah rentan kasus perdagangan orang (Hidayati, 2012; Kedutaan Besar dan Konsulat AS, 2018; Minin, 2011; Utami, 2017). Dapat disimpulkan bahwa, upaya pencegahan perdagangan orang yang utama adalah komunikasi kepada 
masyarakat. Masyarakat harus memiliki pengetahuan dan pemahaman yang cukup tentang isu perdagangan orang agar mampu saling membantu menjaga lingkungan sekitarnya.

Modus dan cara perekrutan korban perdagangan orang merupakan salah satu poin yang urgen untuk dikomunikasikan kepada masyarakat, baik melalui kegiatan sosialisasi tradisional maupun melalui penggunaan media secara optimal. Hal ini dikarenakan seiring dengan perkembangan teknologi dan pandemic yang masih berlangsung, modus dan cara perekrutan korban perdagangan orang pun mulai bergeser pada penggunaan media sosial. Pada akhir Maret 2021, tercatat penetrasi internet Indonesia telah mencapai $76,8 \%$ dari total populasi. Data Internetworldstats bahkan menunjukkan pengguna internet di Indonesia mencapai 212,35 juta dari estimasi total populasi sebanyak 276,3 juta (Katadata, 2021). Tingginya tingkat penetrasi internet merupakan ancaman baru bagi kelompok masyarakat yang rentan terhadap perdagangan orang, khusus anak-anak dan remaja.

Pada Januari 2020, media massa ramai memberitakan kasus perdagangan orang domestik yang berlokasi di Jakarta dengan korban merupakan remaja perempuan kisaran usia 14 hingga 18 tahun. Adapun modus utama perdagangan orang pada kasus tersebut adalah media sosial. Kronologisnya, korban berkenalan dengan pelaku melalui media sosial yang kemudian diimingi-imingi pekerjaan bergaji besar. Faktanya, saat pertemuan terjadi, korban ditipu dan dipaksa menjadi objek prostitusi anak-anak. Data dan banyak studi juga sudah membuktikan bahwa golongan yang paling banyak menjadi korban perdagangan orang adalah perempuan dan anak.

Pada tahun 2019 dan 2020 terdapat sebanyak 244 kasus dan 149 kasus secara berturut-turut yang dilaporkan terkait perdagangan anak seperti pelacuran, pekerja anak hingga adopsi illegal bahkan ditemukan anak bertindak sebagai perantara dengan mucikari (Kompaspedia, 2021). Namun demikian, jumlah kasus yang dilaporkan tersebut hanya segelintir daripada fakta yang ada di lapangan. Fakta yang ada di lapangan, jumlah kasus yang terjadi jauh lebih tinggi daripada angka kasus yang dilaporkan dan tercatat. Data International Labor Organization (ILO) mencatat lebih dari 40 juta orang di dunia menjadi korban Tindak Pidana Perdagangan Orang (TPPO) pada tahun 2020, dengan 1 dari 4 korban tersebut adalah anak-anak. Sementara itu, data terbaru dari Kedubes Amerika Serikat tahun 2020 menyebutkan terdapat sekitar 70.000-80.000 pekerja sesks anak dan dewasa yang banyak tersebar dalam industri pertambahan di Maluku, Jambi, dan Papua (Kompaspedia, 2021).

Tingginya intensitas penggunaan internet pada anak dan remaja karena situasi pandemic yang terus berlanjut, ternyata menjadi celah bagi para pelaku perdagangan orang untuk melancarkan modusnya. Beberapa studi telah membuktikan bahwa tingginya aktivitas penggunaan media sosial oleh anak dan remaja menyebabkan mereka rentan terjebak dalam lingkaran perdagangan orang (Fraser, 2016; Latonero, 2012; Sarkar, 2015). Bahkan selama situasi pandemi saja, angka laporan perdagangan 
anak pada bulan Januari-April 2021 berjumlah 234 anak (Kompaspedia, 2021).

Komisi Perlindungan Anak Indonesia (KPAI) mencatat beberap temuan penting dari banyaknya laporan perdagangan orang terhadap anak dan remaja, diantaranya bahwa usia anak korban prostitusi yang paling rendah adalah 12 hingga 17 tahun sebanyak 98\%, yakni fase remaja awal dengan kapasitas pendidikan Sekolah Dasar; status korban eksploitasi seksual dan pekerja anak tercatat sebagai siswa yang masih aktif bersekolah dengan persentase sebesar 67\%; berdasarkan trend kasus, medium yang paling banyak digunakan untuk merekrut anak korban eksploitasi seksual adalah media sosial sebesar 60\% dan 40\% direkrut secara langsung (didatangi dan diajak). Fakta bahwa medium yang paling banyak digunakan adalah media sosial menunjukkan lemahnya pengawasan orang tua, keluarga dan lingkungan terdekat dalam mengawasi penggunaan internet oleh anak yang mengakibatkan media sosial menjadi pintu masuk perdagangan anak. KPAI mencatat bahwa berdasarkan $60 \%$ kasus prostitusi anak yang dijaring melalui media sosial pada tahun 2021, anak-anak yang menjadi korban dijanjikan sesuatu yang menggiurkan hingga mereka mudah dimobilisasi kemudian dieskploitasi secara seksual (Kompaspedia, 2021).

Data yang telah dipaparkan di atas telah memberikan gambaran tentang betapa besarnya bahaya media sosial bagi anak dan remaja, khususnya di tengah situasi pandemi saat ini. Ketika banyak orang tua dan keluarga kesusahan bertahan secara ekonomi, anak-anak dan remaja juga kesulitan untuk beradaptasi dengan kondisi yang mengharuskan mereka selalu berinteraksi secara daring. Kondisi inilah yang memicu anak-anak dan remaja banyak menggantungkan hidupnya pada internet dan media sosial tanpa pengawasan yang optimal dari orang tua dan keluarga. Keadaan ini menjadi celah masuk bagi pelaku perdagangan orang. Selain itu, kurangnya sosialisasi dan diseminasi informasi tentang perdagangan orang membuat masyarakat, khususnya anak-anak dan remaja, tidak memiliki pengetahuan yang cukup untuk melindungi dirinya sendiri dari bahaya dan ancaman perdagangan orang.

Meskipun kasus perdagangan orang terus meningkat dari tahun ke tahun, isu ini belum menjadi isu tren dan diskusi masyarakat banyak. Salah satu penyebabnya adalah minimnya diseminasi dan informasi kepada masyarakat luas. Oleh karenanya, diperlukan peran aktif pemerintah serta seluruh komponen masyarakat yang berpendidikan dan berpengetahuan, khususnya akademisi dan aktivis, untuk menyosialisasikan dan menyebarkan informasi tentang bahaya dan ancaman perdagangan orang kepada masyarakat luas. Komunikasi kepada masyarakat luas secara intensif dan berkelanjutan diharapkan mampu menambah pengetahuan, menumbuhkan pemahaman, dan menciptakan kesadaran pada masyarakat tentang perdagangan orang, yang pada akhirnya mampu melindungi mereka dari ancaman tersebut.

Kecamatan Jatinangor di Kabupaten Sumedang merupakan salah satu kawasan yang banyak dihuni oleh perguruan tinggi negeri dan swasta. Salah duanya yang terbesar adalah Universitas Padjadjaran dan Institut Teknologi Bandung. Namun 
demikian, hanya 11\% dari total angkatan kerja masyarakat Jatinangor (di atas 15 tahun) yang merupakan lulusan perguruan tinggi. Angkatan kerja kecamatan Jatinangor didominasi oleh lulusan Sekolah Dasar sebesar 40\% dengan tingkat pengangguran sebesar 9,89\% (BPS Kabupaten Sumedang, 2020). Sementara itu, penetrasi internet di kawasan Jatinangor terbilang sangat tinggi karena tuntutan kebutuhan masyarakat pendatang, yaitu mahasiswa di beberapa perguruan tinggi. Hasil pelaksanaan PPM pada tahun 2019 menunjukkan bahwa internet bahkan telah menjadi konsumsi sehari-hari anak-anak berusia 1 tahun ke atas.

Tingkat penetrasi internet yang tinggi dengan jumlah angkatan kerja yang besar dan didominasi oleh kelompok usia 15 - 24 tahun, menempatkan masyarakat Kecamatan Jatinangor rentan terhadap jeratan modus perdagangan orang melalui media sosial. Beberapa pemberitaan pada media daring menyebutkan terdapat kasus eksploitasi seksual terhadap anak dan perempuan yang melibatkan korban dari berbagai daerah di Jawa Barat, terutama Sumedang. Pemberitaan juga menyebutkan bahwa salah satu modus perekrutan pelaku terhadap para korban adalah melalui media sosial (TribunJabar, 2021) (PortalMajalengka, 2021). Kondisi ini mengindikasikan sosialisasi dan edukasi terkait bahaya media sosial sebagai modus perdagangan orang urgen untuk dilakukan di Kabupaten Sumedang, khususnya Kecamatan Jatinangor.

Selain itu, hasil wawancara daring yang dilakukan dengan dua remaja di Kecamatan Jatinangor menunjukkan bahwa meskipun mereka pernah mendengar praktik dengan modus serupa namun mereka tidak tahu hal tersebut masuk dalam kategori TPPO. Salah satu narasumber menyatakan bahwa salah satu tetangganya diajak bekerja ke luar kota dengan iming-iming gaji yang besar oleh kenalannya di Facebook, namun beberapa bulan kemudian yang bersangkutan pulang ke rumah dalam kondisi trauma karena diduga sebagai korban eksploitasi seksual. Namun, narasumber juga mengaku saat itu menganggap tetangganya adalah korban penipuan, dan belum mengetahui bahwa praktik tersebut termasuk dalam kategori perdagangan orang (Narasumber, 2021). Hal ini mengindikasikan bahwa narasumber belum familiar dengan isu perdagangan orang atau TPPO. Oleh karenanya, kegiatan pengabdian dalam bentuk sosialisasi dan edukasi tentang bahaya media sosial sebagai modus perdagangan orang bagi remaja di Jatinangor bertujuan untuk meningkatkan pengetahuan dan kesadaran remaja dan masyarakat setempat tentang isu tersebut.

\section{Metode}

Sasaran atau subjek kegiatan sosialisasi ini adalah masyarakat di Kecamatan Jatinangor yang merupakan lokasi kampus Universitas padjadjaran. Pemilihan sasaran atau subjek pengabdian ini berdasarkan pada data yang menunjukkan bahwa angka pengguna internet tertinggi di Indonesia adalah di Provinsi Jawa Barat yang mencapai lebih dari 35 juta pengguna (Kompaspedia, 2021). Selain itu, Jawa Barat merupakan salah satu dari lima provinsi zona merah perdagangan orang dengan jumlah kasus yang 
terus meningkat dari tahun ke tahun (Antara, 2017).

Oleh karena kondisi pandemi, maka kegiatan sosialisasi pun dilakukan secara daring dengan menyelenggarakan Webinar dengan judul "Potret Buram Korban Tindak Pidana Perdagangan Orang". Tujuan pelaksanaan webinar ini adalah untuk menyosialisasikan dan mendiseminasikan informasi tentang isu perdagangan orang yang ada di Indonesia, khususnya yang terjadi di Jawa Barat. Pada akhir webinar, peserta diharapkan dapat mengetahui, memahami, dan menyadari tentang bahaya dan ancaman perdagangan orang yang sangat mungkin terjadi di sekitar lingkungannya, termasuk modus perekrutan melalui media sosial yang harus diwaspadai.

Webinar dilaksanakan pada tanggal 7 Agustus 2021 Pkl 13.00 - 16.30 WIB. Webinar ini menghadirkan pembicara dari beberapa latar belakang yang berbeda yang mampu memberikan informasi yang relevan dan penting untuk mencapai tujuan akhir webinar. Webinar dilaksanakan dengan konsep seminar, yakni terdapat lima pembicara yang masing-masing mempresentasikan materinya selama 20-30 menit. Penyampaian materi oleh pembicara dipandu oleh seorang moderator. Pada akhir sesi presentasi pembicara, sesi tanya jawab dan diskusi dibuka bagi seluruh peserta Webinar yang hadir. Sesi tanya jawab dan diskusi berlangsung selama 60 menit.

Peserta Webinar terdiri dari 76 orang yang terdiri dari pelajar SMP dan SMA, mahasiswa, juga masyarakat umum pada rentang usia 15 - 24 tahun. Sebesar 65,8\% peserta berdomisili di Jatinangor dan sekitarnya, sedangkan sisanya berasal dari daerah lainnya di pulai Jawa, seperti Jakarta, Indramayu, dan Cirebon. Hasil pre-test dan posttest dianalisis menggunakan teknik analisis deskriptif kuantitatif untuk memetakan tingkat pengetahuan dan pemahaman peserta sebelum maupun sesudah pelaksanaan webinar.

Berikut adalah gambaran tahapan persiapan, pelaksanaan, hingga evaluasi pelaksanaan Webinar "Potret Buram Korban Tindak Pidana Perdagangan Orang": 


\section{Melakukan survei daring melalui media sosial tentang isu perdagangan orang bagi masyarakat Kec. Jatinangor}

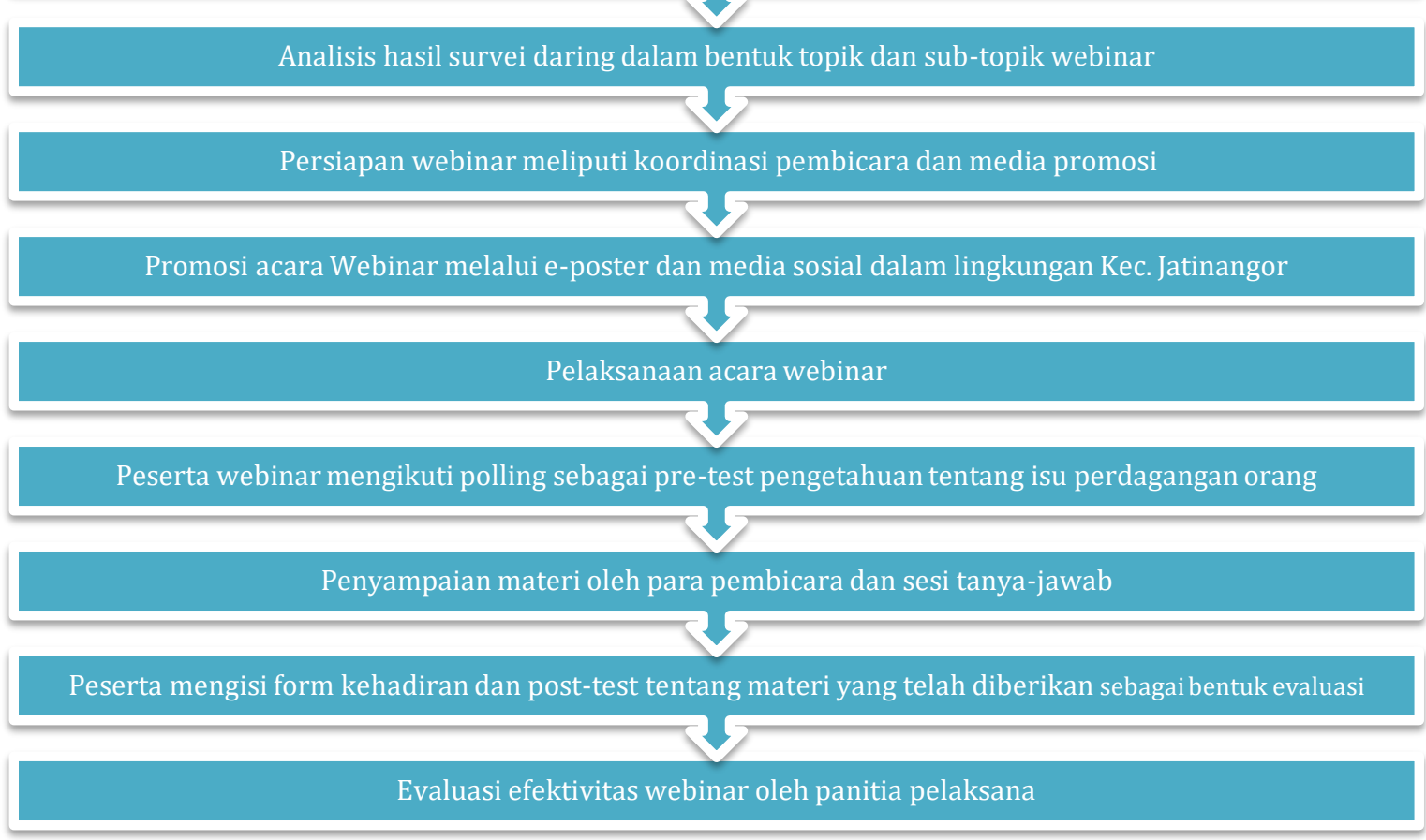

Gambar 1. Alur pelaksanaan kegiatan sosialisasi dalam format Webinar Sumber : Data Olahan, 2021

\section{Hasil dan Pembahasan}

\section{Hasil Kegiatan}

Kegiatan sosialisasi bahaya media sosial sebagai media perekrutan perdagangan orang bagi remaja di Kecamatan Jatinangor dilaksanakan dalam format Webinar atau seminar secara daring. Pelaksanaan webinar tak lepas dari kondisi pandemi yang masih berlangsung di Indonesia. Kegiatan webinar tersebut berlangsung pada tanggal 7 Agustus $2021 \mathrm{Pkl} 13.00$ - 16.30 WIB melalui media zoom meeting.

Pada awalnya, sasaran webinar tersebut adalah anak-anak usia sekolah, yakni yang sedang duduk di bangku Sekolah Menengah Atas (SMA) di Kecamatan Jatinangor. Namun, tentu saja hal tersebut tidak mudah dilakukan ditengah kondisi pandemi seperti saat ini. Oleh karenanya, kami berusaha menjaring masyarakat usia anak-anak dan remaja di Kecamatan Jatinangor melalui media sosial, yakni Instagram dan TikTok. Kedua media sosial tersebut dibuat dan dikelola oleh tim mahasiswa yang merupakan bagian dari tim dosen Fakultas Ilmu Komunikasi Universitas Padjadjaran yang sedang melaksanakan program pengabdian pada masyarakat.

Tim pelaksana kegiatan pengabdian ini merupakan tim dosen Fakultas Ilmu Komunikasi Universitas Padjadjaran yang melibatkan 10 mahasiswa aktif dari berbagai 
fakultas di Universitas Padjadjaran melalui program Kuliah Kerja Nyata Pengabdian pada Masyarakat Integratif Virtual atau KKN PPM Integratif Virtual. Program KKN PPM Integratif Virtual merupakan integrasi kuliah KKN yang merupakan mata kuliah wajib universitas bagi mahasiswa sarjana dan sarjana terapan di Universitas Padjadjaran dengan kegiatan pengabdian masyarakat dosen yang dilaksanakan secara daring. Pada pelaksanaan program ini, mahasiswa mengikuti topik PPM yang dimiliki oleh dosen dan mengimplementasikannya secara bersama-sama dengan menggunakan berbagai media daring di bawah bimbingan dosen.

Kegiatan pengabdian yang diusulkan oleh tim dosen adalah sosialisasi bahaya media sosial sebagai modus perdagangan orang bagi remaja di Kecamatan Jatinangor. Adapun pelaksanaan kegiatan pengabdian ini terdiri dari tiga tahapan utama, yakni tahapan persiapan, implementasi, dan pasca implementasi. Pada tahap persiapan, tim memutuskan untuk melakukan survey pendahuluan melalui media sosial untuk memetakan pengetahuan dan ketertarikan tentang isu perdagangan orang serta perilaku penggunaan internet khalayak sasaran.

Data hasil survey pendahuluan tersebut menunjukkan bahwa sebesar 96\% dari 76 peserta webinar pernah mendengar istilah/term perdagangan orang, namun $46 \%$ mengaku tidak pernah mendengar istilah/term TPPO (Tindak Pidana Perdagangan Orang). Selain itu, sebanyak $25 \%$ peserta tidak mampu mengidentifikasi jenis-jenis praktik perdagangan orang dan sebanyak $26 \%$ belum mengetahui cara atau modus pelaku perdagangan orang merekrut calon korban. Di sisi lain, hasil survey menunjukkan bahwa seluruh responden tertarik dan ingin mengetahui lebih banyak tentang isu perdagangan orang.

Hasil survey juga berhasil memetakan perilaku penggunaan internet responden, bahwa seluruh responden menggunakan internet untuk mengakses media sosial dan seluruhnya juga menggunakan smartphone untuk mengaksesnya. Data menunjukkan bahwa media sosial yang paling banyak digunakan oleh responden adalah Instagram (88\%), WhatsApp (81\%), Line Messanger (58\%), Twitter (49\%), Facebook (47\%), dan TikTok (32\%). Responden juga menggunakan internet dengan intensitas cukup tinggi dengan rata-rata 3-5 jam per hari (68\%) dan sisanya menggunakan internet di atas 5 jam per harinya (32\%).

Berdasarkan hasil survey pendahuluan tersebut, maka diputuskan bahwa kegiatan sosialisasi bahaya media sosial sebagai modus perdagangan orang dilakukan melalui tiga media digital, yakni media sosial (melalui platform Instagram dan TikTok), Webinar, dan Podcast. Langkah selanjutnya dalam tahap persiapan adalah membuat akun media sosial, merancang pelaksanaan Webinar, dan merancang perekaman materi Podcast. Akun media sosial pada platform Instagram dan TikTok dibuat dengan username @peduliTPPO. kedua akun tersebut berfungsi untuk menyosialisasikan tentang isu perdagangan orang dan juga mempromosikan kegiatan Webinar. 
Pada tahap implementasi, kegiatan webinar dipromosikan melalui akun Instagram dan TikTok @peduliTPPO untuk menjaring sebanyak mungkin peminat anak-anak dan remaja, khususnya yang berada di sekitar Kecamatan Jatinangor. Webinar dengan judul "Potret Buram Korban Tindak Pidana Perdagangan Orang" menghadirkan lima narasumber dengan topik dan materi yang berbeda dan saling berkaitan. Webinar yang dilaksanakan pada hari Sabtu, 7 Agustus 2021 pkl. 13.00 - 16.30 melalui media zoom meeting ini berhasil mendatangkan 76 peserta. Peserta sebagian besar terdiri dari remaja dalam rentang usia 17-21 tahun sebanyak 65,8\% sedangkan sisanya berada pada rentang usia 22 - 55 tahun. Selain itu, 65,8\% peserta tersebut berstatus pelajar dan mahasiswa yang berdomisili di sekitar kawasan Jatinangor.

Pelaksanaan acara webinar terdiri dari tiga sesi utama, yakni sesi pengisian polling melalui aplikasi zoom meeting terkait pengetahuan dasar tentang isu perdagangan orang dan perilaku penggunaan internet peserta webinar yang dipandu langsung oleh moderator acara; sesi penyampaian materi oleh pembicara; serta sesi tanya-jawab dan diskusi. Pada sesi pertama, moderator meminta peserta webinar untuk mengisi polling dalam aplikasi zoom meeting sebanyak 10 pertanyaan. Hasil polling menunjukkan bahwa seluruh peserta secara aktif menggunakan media sosial dengan frekuensi dan intensitas yang cukup tinggi. Sebanyak $67 \%$ peserta menggunakan media sosial setiap hari dan sebanyak 68\% mengaku menggunakannya selama 1 - 5 jam per hari. Peserta juga menggunakan beberapa platform media sosial yang berbeda dengan persentase seperti yang terlihat pada gambar 2 .



Gambar 2. Platform media sosial yang paling banyak digunakan oleh peserta Webinar Sumber: Data Olahan Pre-Test

Data polling menunjukkan bahwa media sosial yang paling banyak digunakan peserta secara berturut-turut adalah Instagram, WhatsApp, LINE messanger, Twitter, dan Facebook. 
Di sisi lain, data polling juga menunjukkan bahwa hampir semua peserta pernah mendengar istilah perdagangan orang (96\%), namun hanya sebagian atau setengah dari jumlah peserta yang pernah mendengar istilah TPPO (54\%). Selain itu, hasil polling menemukan bahwa sebagian besar peserta mendapatkan informasi tentang perdagangan orang atau TPPO dari media sosial (84\%), televisi $(70 \%)$, dan portal berita online (67\%) seperti yang ditunjukkan oleh gambar 3 berikut.

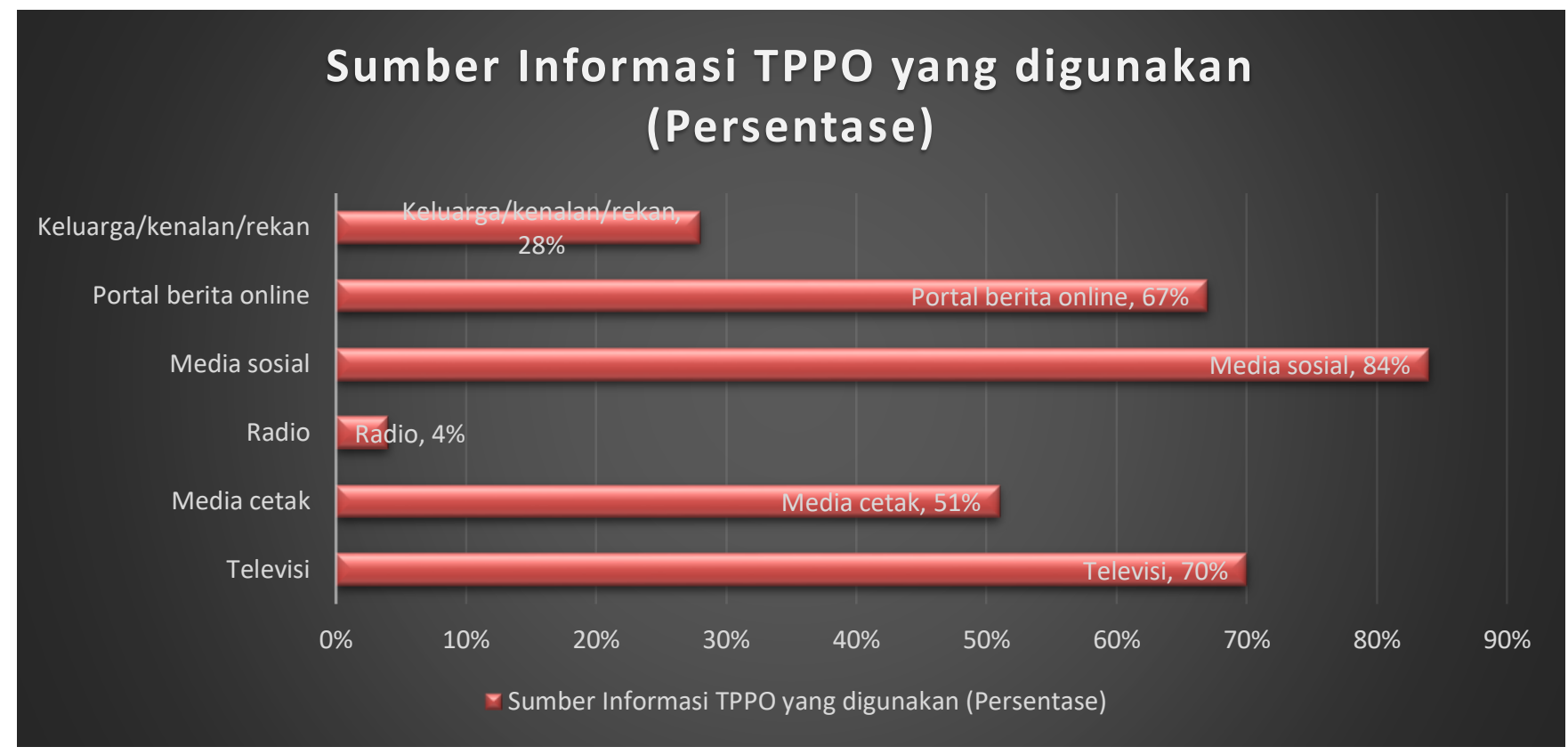

Gambar 3. Sumber informasi perdagangan orang bagi peserta Webinar Sumber: Data Olahan Pre-Test

Data tersebut menunjukkan bahwa internet dan televisi merupakan dua sumber informasi utama peserta Webinar. Ketika peserta dihadapkan dengan pertanyaan yang memuat semua jenis praktik perdagangan orang, sebanyak $75 \%$ peserta mampu menjawab dengan tepat bahwa semua pilihan yang ditampilkan (tenaga kerja illegal, eksploitasi seksual pada perempuan dan anak, pengantin pesanan, adopsi anak dengan imbalan uang, pernikahan dini dengan imbalan uang, semua benar) adalah termasuk praktik perdagangan orang. Data tersebut mengindikasikan bahwa terdapat $25 \%$ peserta yang belum mampu mengidentifikasi praktik perdagangan orang dengan tepat. Sementara itu, ketika dihadapkan pada pertanyaan "Ketika anda menemukan seseorang yang tidak anda kenal mengontak anda melalui salah satu akun media sosial anda, kemudian menawari anda pekerjaan dengan iming-iming gaji besar, apakah hal tersebut patut dicurigai sebagai salah satu modus perdagangan orang?", terdapat $9 \%$ peserta yang menjawab "Tidak". Meskipun kecil, namun angka tersebut menunjukkan masih ada peserta yang belum mampu mengidentifikasi penipuan perdagangan orang berkedok tawaran pekerjaan di media sosial. 
Pertanyaan terakhir pada polling tersebut mencoba memetakan pengetahuan peserta tentang modus dan media perekrutan korban perdagangan orang, yang terdiri dari keluarga, kenalan, media sosial, dan pilihan benar semua. Hanya sebanyak $74 \%$ peserta yang menjawab pilihan "benar semua". Dengan kata lain, 26\% peserta belum mengetahui bahwa modus dan media perekrutan korban perdagangan manusia, tidak hanya melalui keluarga dan kenalan, tapi juga melalui media sosial.

Pada akhir sesi polling, moderator menayangkan semua hasil polling kepada peserta sekaligus menyampaikan poin-poin penting untuk menjadi perhatian peserta, diantaranya adalah pertama, pentingnya untuk mengetahui dan mengenal isu perdagangan orang, terutama tentang modus dan cara perekrutan korban perdagangan orang; kedua, pelaku perdagangan orang tidak hanya merekrut secara langsung melalui keluarga dan kenalan, tapi juga melalui media sosial dengan iming-iming tertentu; ketiga, media sosial merupakan salah satu modus dan cara perekrutan korban perdagangan orang yang sangat rentan bagi anak dan remaja, oleh karenanya sangat penting untuk mengawasi penggunaan internet dan media sosial oleh anak dan remaja.

Setelah sesi polling, setiap pembicara menyampaikan materinya masing-masing. Pembicara pertama adalah seorang penyintas TPPO yang telah sukses menjadi pengusaha dan pegiat anti perdagangan orang serta ketua Keluarga Migran Indonesia (KAMI) provinsi Jawa Barat, Darwinah. Pembicara pertama menceritakan pengalamannya sebagai seorang mantan korban perdagangan orang, dimulai dari proses perekrutan hingga persoalan yang dihadapinya dan bagaimana beliau melepaskan diri dari praktik perdagangan orang tersebut. Pembicara juga menyampaikan tentang pentingnya memerhatikan sesama di dalam lingkungan tinggalnya masing-masing karena pelaku perdagangan orang bisa berada di mana saja dengan menggunakan modus apa saja. Darwinah juga menegaskan bahwa persoalan utama tingginya angka perdagangan orang adalah tingginya angka kemiskinan dan rendahnya perhatian pemerintah terhadap masyarakat miskin dan tidak mampu.

Pembicara kedua adalah dosen Fakultas Ilmu Komunikasi Universitas padjadjaran, Evie Ariadne Shinta Dewi. Beliau berbicara dengan kapasitas sebagai seorang peneliti yang sedang melakukan penelitian dengan judul "Akselerasi SDG's melalui Optimalisasi Komunikasi Pemerintah dan Peran Civil Society dalam Upaya Penanganan Human Trafficking". Pemaparan materinya diantaranya berdasarkan data dan fakta temuan di lapangan tentang praktik perdagangan orang, khususnya modus dan cara yang digunakan untuk merekrut korban. Pembicara kedua juga berbicara tentang bahaya media sosial sebagai media baru perekrutan korban perdagangan orang yang telah memakan ratusan korban anak-anak dan perempuan selama masa pandemi.

Pembicara ketiga adalah Kepala UPTD Dinas Pemberdayaan Perempuan Perlindungan Anak dan Keluarga Berencana (DP3AKB) provinsi Jawa Barat, Anjar Yusdinar. Pembicara ketiga menyampaikan materi tentang praktik TPPO dan dampaknya terhadap korban, khususnya yang terjadi dalam kawasan provinsi Jawa 
Barat. Pembicara ketiga mewakili perspektif pemerintah dalam melaksanakan upaya pencegahan dan penanganan kasus perdagangan orang di tingkat provinsi.

Pembicara keempat adalah seorang jurnalis KOMPAS dan juga pegiat anti kekerasan terhadap perempuan dan anti perdagangan orang, Sonya Helen Sinombor. Pembicara keempat menyampaikan materi tentang peran jurnalis dan media dalam upaya memerangi perdagangan orang. Menurut pembicara keempat, sayangnya isu perdagangan orang tidak menarik bagi wartawan pada umumnya. Bahkan, seringkali wartawan hanya meliput tentang perdagangan orang ketika terjadi permasalahan pada korban. Pembicara keempat juga menegaskan bahwa penyebab utama tingginya angka perdagangan orang di Indonesia adalah rendahnya tingkat pendidikan dan ketidaktahuan masyarakat luas tentang isu perdagangan orang. Oleh karenanya, peran wartawan dan media sangat penting untuk membesarkan isu tersebut agar dapat menjangkau lebih banyak masyarakat di Indonesia. Pembicara juga berpendapat bahwa kegiatan sosialisasi seperti Webinar ini sangat penting untuk dapat menyebarkan informasi tentang isu perdagangan orang kepada masyarakat luas.

Sementara itu, pembicara kelima adalah seorang mantan anggota DPR RI dan pegiat anti perdagangan orang yang juga merupakan Ketua Jaringan Nasional Anti TPPO, Rahayu Saraswati Djojohadikusumo. Pembicara kelima menyampaikan materi tentang pentingnya peran support system dalam upaya memerangi perdagangan orang. Pembicara menekankan pentingnya peran aktif seluruh komponen masyarakat untuk dapat menggaungkan isu perdagangan orang. Menggaungkan isu perdagangan orang menjadi sangat penting untuk membantu masyarakat mengetahui, memahami, dan menyadari ancaman perdagangan orang yang bisa saja terjadi pada keluarga dan lingkungan sekitarnya.

Setelah semua sesi pemaparan materi selesai, sesi tanya-jawab dibuka bagi peserta Webinar. Antusiasme dan partisipasi aktif peserta sudah terlihat bahkan sejak pembicara pertama selesai menyampaikan materi. Hal ini ditunjukkan dengan banyaknya pertanyaan yang masuk pada kolom chat aplikasi zoom meeting. Terdapat sangat banyak pertanyaan yang masuk kepada kelima pembicara. Karena keterbatasan waktu, panitia memilihkan beberapa pertanyaan yang dipandang paling urgen untuk dijawab oleh para pembicara. Selain menjawab pertanyaan peserta secara langsung, para pembicara pun aktif menjawab pertanyaan peserta melalui kolom chat zoom meeting ketika pergantian waktu bicara. Di sisi lain, peserta tidak hanya meninggalkan pertanyaan di kolom chat, namun juga menyampaikan opini/gagasannya serta pengalamannya tentang perdagangan orang. Hasil penyisiran komentar-komentar yang masuk dari peserta, ditemukan bahwa sebagian peserta baru mengetahui dan memahami praktik dan modus perdagangan orang selain tenaga kerja illegal. Selain itu, peserta juga menyuarakan kekagetannya terhadap fakta-fakta mengerikan yang dialami oleh korban perdagangan orang. Hal-hal tersebut mengindikasikan bahwa tujuan Webinar untuk menambah pengetahuan, meningkatkan pemahaman dan kesadaran 
peserta tentang ancaman isu perdagangan orang telah tercapai.

Sebelum mengakhiri acara, peserta diminta untuk mengisi form post-test berisi beberapa pertanyaan evaluatif untuk mengetahui tingkat pengetahuan dan pemahaman peserta setelah menyimak materi dari para pembicara. Hasil post-test menunjukkan bahwa peserta telah mengetahui dan memahami beberapa poin penting isu perdagangan orang yang meliputi: 1) jenis atau bentuk praktik yang tergolong dalam perdagangan orang; 2) modus atau cara-cara pelaku merekrut korban perdagangan orang; 3) hal-hal yang harus dilakukan jika mengetahui atau melihat orang sekitar yang dicurigai menjadi korban perdagangan orang; 4) pihak-pihak yang harus dihubungi ketika mengetahui atau melihat praktik perdagangan orang; 5) dan bahaya media sosial bagi anak dan remaja yang rentan terjerumus dalam perdagangan orang.

Melalui penyelenggaraan Webinar tersebut, tim pengabdian berharap diseminasi informasi dan sosialisasi tentang isu perdagangan orang tersebut dilanjutkan atau diteruskan oleh peserta kepada orang-orang di sekitarnya, khususnya kepada anak-anak dan remaja lainnya. Untuk mampu menarik perhatian masyarakat luas terhadap isu perdagangan orang, kegiatan sosialisasi serupa tidak bisa hanya dilakukan satu kali. Guna menyadarkan masyarakat luas tentang ancaman perdagangan orang, dibutuhkan lebih banyak kegiatan serupa yang dilakukan secara berkelanjutan dan sistematis. Harapannya, dimulai dari sekelompok kecil orang yang menghadiri Webinar tersebut, diseminasi informasi dapat terus berlanjut secara individual melalui jaringan kontak masing-masing.

\section{Diskusi}

Berdasarkan hasil polling yang dilakukan pada sesi pertama Webinar, ditemukan bahwa intensitas penggunaan dan akses media sosial peserta cukup tinggi yang menyebabkannya rentan terhadap ancaman perdagangan orang melalui media sosial. Hal ini seperti yang telah ditemukan dalam beberapa studi, bahwa aktivitas penggunaan media sosial yang tinggi oleh remaja menyebabkannya rentan terjerumus perdagangan orang (Fraser, 2016; Latonero, 2012; Sarkar, 2015).

Maraknya penggunaan media sosial sebagai media untuk merekrut korban perdagangan orang perlu menjadi perhatian khusus. Perlu adanya tindakan preventif yang dibangun secara sistematis melalui media sosial. Studi terhadap beberapa akun media sosial lembaga/institusi pemerintahan yang tergabung dalam Gugus Tugas Pencegahan dan Penanganan Tindak Pidana Perdagangan Orang menunjukkan bahwa akun-akun media sosial yang ada belum digunakan untuk menyosialisasikan dan mengedukasi masyarakat tentang ancaman perdagangan orang, melainkan untuk mempromosikan event dan acara yang telah dilakukan oleh institusi tersebut (Pratamawaty, Shinta Dewi, \& Limilia, 2021).

Selain itu, hasil polling juga mengindikasikan bahwa meskipun peserta sudah mengetahui istilah perdagangan orang, namun banyak dari mereka yang belum mampu 
mengidentifikasi jenis atau bentuk praktik perdagangan orang. Hasil lainnya bahkan menunjukkan peserta tidak memiliki pengetahuan yang cukup tentang modus dan cara pelaku merekrut korban perdagangan orang. Hal ini sejalan dengan rekomendasi beberapa studi bahwa sangat penting dan urgen bagi pemerintah untuk mengomunikasikan isu perdagangan orang kepada masyarakat luas melalui sosialisasi, diseminasi informasi, edukasi dan pelatihan (Hidayati, 2012; Kedutaan Besar dan Konsulat AS, 2018; Minin, 2011; Utami, 2017).

Meskipun demikian, penulis berpandangan bahwa kompleksitas isu perdagangan manusia bersifat multidimensional sehingga tidak cukup hanya ditangani oleh pemerintah. Isu ini menuntut peran aktif seluruh komponen masyarakat untuk bersama-sama dan berkelanjutan mengupayakan sosialisasi, diseminasi informasi, edukasi, dan penyadaran sosial agar masyarakat tidak lagi menjadi korban.

\section{Simpulan}

Kegiatan sosialisasi yang telah dilaksanakan menghasilkan beberapa temuan penting, diantaranya: 1) khalayak sasaran belum memiliki pengetahuan yang cukup tentang perdagangan orang untuk dapat melindungi dirinya dari ancaman praktik tersebut; 2) khalayak sasaran berada pada rentang usia 17-21 tahun, yang dapat diklasifikasikan ke dalam remaja akhir, dengan tingkat penggunaan dan interaksi dengan media sosial yang tinggi sehingga menyebabkannya rentan terhadap ancaman perdagangan orang.

Selain beberapa temuan di atas, berdasarkan hasil post-test, tujuan pelaksanaan kegiatan sosialisasi telah tercapai dengan peserta telah mengetahui dan memahami: 1) jenis atau bentuk praktik yang tergolong dalam perdagangan orang; 2) modus atau caracara pelaku merekrut korban perdagangan orang; 3) hal-hal yang harus dilakukan jika mengetahui atau melihat orang sekitar yang dicurigai menjadi korban perdagangan orang; 4) pihak-pihak yang harus dihubungi ketika mengetahui atau melihat praktik perdagangan orang; 5) dan bahaya media sosial bagi anak dan remaja yang rentan terjerumus dalam perdagangan orang.

Meskipun demikian, pelaksanaan kegiatan sosialisasi ini bukan tanpa hambatan. Keterbatasan yang dialami adalah sulitnya mendapatkan khalayak sasaran yang sesuai dengan target, yaitu siswa SMA, karena kondisi pandemi yang memaksa pelaksanaan acara dalam format daring. Format daring menyebabkan panitia kesulitan memobilisasi siswa untuk mau dan bisa hadir sebagai peserta webinar.

Selanjutnya, penulis merekomendasikan bagi pemerhati isu perdagangan orang untuk secara aktif mengomunikasikan, menyosialisasikan, mendiseminasikan informasi, dan mengedukasi kelompok masyarakat rentan perdagangan orang, seperti perempuan dan anak-anak, khususnya di lima provinsi zona merah perdagangan orang. 


\section{Referensi}

Antara. (2017). Lima Provinsi Masuk Zona Merah Perdagangan Manusia. Retrieved from republika.co.id website:

https://nasional.republika.co.id/berita/nasional/umum/17/11/23/ozvhkw383lima-provinsi-masuk-zona-merah-perdagangan-manusia

BPS Kabupaten Sumedang, S. (2020). Kabupaten Sumedang dalam Angka 2021. Sumedang: BPS KABUPATEN SUMEDANG.

Dalimoenthe, I. (2018). Pemetaan Jaringan Sosial dan Motif Korban Human Trafficking pada Perempuan Pekerja Seks Komersial. Jupiis: Jurnal Pendidikan Ilmu-Ilmu Sosial, 10(1), 91. https://doi.org/10.24114/jupiis.v10i1.8430

Daniah, R., \& Apriani, F. (2017). Kebijakan Nasional Anti-Trafficking dalam Migrasi Internasional/National Anti-Trafficking Policies in International Migration. 137-162. https://doi.org/http://dx.doi.org/10.22212/jp.v8i2.1140

Fraser, C. (2016). An Analysis of the Emerging Role of Social Media in Human Trafficking: Examples from Labour and Human Organ Trading. International Journal of Development Issues, 15(2), 98-112.

Hidayati, M. N. (2012). Upaya Pemberantasan dan Pencegahan Perdagangan Orang Melalui Hukum Internasional dan Hukum Positif Indonesia. Jurnal Al-Azhar Indonesia Seri Pranata Sosial, 1(3), 163-174.

Katadata. (2021). Penetrasi Internet Indonesia Urutan ke-15 di Asia pada 2021.

Kedutaan Besar dan Konsulat AS, I. (2018). Laporan Tahunan Perdagangan Orang 2018. Retrieved from Laporan Resmi website: https://id.usembassy.gov/id/ourrelationship-id/official-reports-id/laporan-tahunan-perdagangan-orang-2018/

Kompaspedia. (2021). Menutup Celah Perdagangan Anak.

Latonero, M. (2012). Human Trafficking Online: The Role of Social Networking Sites and Online Classifieds. SSRN Electronic Journal, (September). https://doi.org/10.2139/ssrn.2045851

Minin, D. (2011). Strategi Penanganan Trafficking di Indonesia. Kanun Jurnal Ilmu Hukum, 54, 21-31.

Nabal, A. R. J., Wea, L. V., \& Gulo, S. (2018). Telaah Human Trafficking di Indonesia.

Narasumber. (2021, Juli). Wawancara Pra-riset. (B. Pratamawaty, Interviewer)

Niko, N. (2016). Kemiskinan Sebagai Penyebab Strategis Praktik Human Trafficking di 
Kawasan Perbatasan Jagoi Babang (Indonesia-Malaysia) Kalimantan Barat. Prosiding Seminar Nasional INDOCOMPAC, 515-524.

Pratamawaty, B. B., Shinta Dewi, E. A., \& Limilia, P. (2021). Human Trafficking Countermeasure Efforts of the Indonesian Government on Social Media. Review of International Geographical Education, 11(5), 57-67. https://doi.org/10.48047/rigeo.11/5/6

PortalMajalengka. (2021, Agustus 16). portalmajalengka. Retrieved from portalmajalengka.pikiran-rakyat.com: https://portalmajalengka.pikiranrakyat.com/ciayumajakuning/pr-832408241/polisi-ungkap-kasus-perdaganganorang-di-indramayu-begini-modusnya?page $=2$

Sarkar, S. (2015). Uses of Technology in Human Trafficking Networks and Sexual Exploitation: A Cross Sectional Multi-country Study. Transnational Social Review, 5(1), 55-68.

Satriani, R. A., \& Muis, T. (2013). Studi tentang perdagangan manusia pada remaja putri jenjang sekolah menengah di kota Surabaya. Jurnal BK Unesa, 04(1), 67-78.

Sylvia, I. (2014). Faktor Pendorong dan Penarik Perdagangan Orang (Human Trafficking) di Sumatera Barat. Humanus, XIII(2), 193-202. https://doi.org/https://doi.org/10.24036/jh.v13i2.4728

TribunJabar. (2021, Januari 18). TribunJabar.id. Retrieved from jabar.tribunnews.com: https://jabar.tribunnews.com/2021/01/18/enam-perempuan-asal-subangsumedang-dan-malang-jadi-korban-perdagangan-orang-di-kota-bandung

Utami, P. (2017). Upaya Pemerintah Indonesia Dalam Mengatasi. 5(4), 1257-1272.

Wulandari, A. R. A. (2016). Kerjasama bnp2tki dengan iom dalam menangani human trafficking tenaga kerja Indonesia di Malaysia Periode 2011-2015. Journal of International Relations, 2(1), 189-196. 